Квітування ЛА-гібридів в умовах відкритого грунту Полісся i Лісостепу України починається у III декаду червня - I декаді липня, через 30-40 діб від початку фази видимої бутонізації та через 67-70 діб від початку вегетації, і не закінчується плодоношенням. Надземні пагони відмирають у жовтні.

\title{
Література:
}

1. Matthews V. The International Lily Register and Checklist: Fourth edition. London. 2007. 948 p.

DOI https://doi.org/10.30525/978-9934-26-047-6-7

\section{AGROBACTERIUM-MEDIATED TRANSFORMATION OF PETUNIA HYBRIDA WITH THAUMATIN II GENE AS A MODEL FOR INVESTIGATION OF PLEIOTROPIC EFFECTS OF THE GENE}

\author{
Ovcharenko O. O. \\ Candidate of Biological Sciences, Scientific Researcher \\ Institute of Cell Biology and Genetic Engineering National Academy \\ of Sciences of Ukraine \\ Kyiv, Ukraine \\ Potrokhov A. O. \\ Master of Science, Senior Engineer \\ Institute of Cell Biology and Genetic Engineering National Academy \\ of Sciences of Ukraine \\ Kyiv, Ukraine

\section{Sosnovska D. I.} \\ Master of Science Student \\ Educational and Research Center "Institute of Biology and Medicine» \\ of Taras Shevchenko National University of Kyiv \\ Kyiv, Ukraine
}

Thaumatin II is a super sweet protein derived from the West African plant Thaumatococcus daniellii Benth. This protein have been attracted human attention as a low-calorie sweetener and flavor modifier [1]. The 
protein belongs to a family of PR (pathogenesis-related) proteins. Most of the members of this family are involved in plant pathogen defense. Recent investigations showed pleiotropic function of this gene [2]. Plants transformed with the heterologous taumatin gene demonstrated increased resistance to some phytopathogenic fungi [3]. Damage caused by fungal diseases significantly reduces commercial value of ornamental plants and demands on the wide application of fungicides. Production of genetically modified ornamental plants with increased resistance to phytopathogenic fungi can be an alternative to artificial plant protection chemicals.

Transgenic plants of petunia were obtained by Agrobacterium-mediated transformation. Agrobacterium tumefaciens strain GV3101 with plasmid vector pNMD46732 containing heterologous thaumatin under the control of rice amylase apoplastic targeting signal. Gene bar (phosphinotricin$\mathrm{N}$-acetyltransferase) was used for selection of transgenic plants. Transformation of leaf disks resulted in regeneration of herbicide-resistant plants. The influence of time of co-culture with Agrobacterium tumefaciens, conditions of regeneration and selection on the efficiency of Petunia hybrida transformation were investigated. Factors such as co-culture period, content of different plant growth regulators in cultivation media and different concentrations of selective agent (glufosinate ammonium) were validated. The PCR analysis confirmed the taumatin II gene integration into the petunia genome. T0 plants were transferred to soil and grown to the maturity to obtain T1 seeds. Microbiological tests revealed higher resistance of leaves from transgenic lines to phytopathogenic fungi Alternaria alternata and Botrytis cynerea. compared to the control thaumatin free plants.

\section{References:}

1. Van der Wel H, Loeve K (1972). Isolation and characterization of thaumatin I and II, the sweet-tasting proteins from Thaumatococcus daniellii Benth. European Journal of Biochemistry 31:221-225.

2. de Jesús-Pires C, Ferreira-Neto JRC, Pacifico Bezerra-Neto J. et al Plant Thaumatin-like Proteins: Function, Evolution and Biotechnological Applications. Curr Protein Pept Sci. 2020;21(1):36-51. doi: 10.2174/ 1389203720666190318164905. PMID: 30887921.

3. Rajam, M.V., Chandola, N., Saiprasad Goud, P. et al (2007). Thaumatin gene confers resistance to fungal pathogens as well as tolerance to abiotic stresses in transgenic tobacco plants. Biol Plant 51, 135-141 https://doi.org/10.1007/s10535-007-0026-8 